\title{
Motor function evaluation of hydrocephalus children
}

\author{
Aida Carla Santana de Melo Costa', Carlos Umberto Pereira², Edna Aragão Farias Cândido³
}

Ambulatório do Hospital Universitário do município de Aracaju.

\begin{abstract}
Objectives: To evaluate the kinetic functional condition of children with hydrocephalus; to identify the condition of the muscle tone; to verify the static and dynamic functional activities; and to verify the association between tone changes and functional activities. Method: A cross-sectional, descriptive, exploratory and field study, using qualitative and quantitative approach, performed at the University Hospital in Aracaju city, from August 2009 to March 2010. Results: From 50 evaluated children, 30 (60\%) had hypertonia; 10 (20\%) were hypotonic; and 10 (20\%) did not show muscle tone alteration. The age average was considerably lesser in hypertonic children and higher in hypotonic and without tone alteration children. The average of carried through surgeries was more expressive in hypertonic children. Motor sequels had been present in $92 \%$ of the sample. The static functional activities, as well as dynamic functional activities, were lower in hypertonic children $(p<0,0001)$ and higher in hypotonic and normal tone children. Conclusions: Muscle tone exacerbation is more present in hydrocephalus children and motor function is impaired, being the neuropsychomotor development delayed more evident in spastic children group and less pronounced in children with normal muscle tone.
\end{abstract}

\section{KEY-WORDS}

Child, motor activity, hydrocephalus, muscle tone.

\section{RESUMO}

Avaliação da função motora de crianças com hidrocefalia

Objetivos: Avaliar o quadro cinético-funcional de crianças com hidrocefalia; identificar a condição do tônus muscular; verificar as atividades funcionais estáticas e dinâmicas; verificar a associação entre as alterações de tônus e as atividades funcionais nas crianças com hidrocefalia. Método: Estudo transversal, de caráter descritivo, exploratório e de campo, sob abordagem qualiquantitativa, realizado no ambulatório do Hospital Universitário, do município de Aracaju, no período de agosto de 2009 a março de 2010. Resultados: Das 50 crianças avaliadas, 30 (60\%) apresentavam hipertonia; 10 (20\%) eram hipotônicas; 10 (20\%) não apresentavam alteração de tônus muscular. A média de idade foi consideravelmente menor nas crianças hipertônicas em relação às crianças hipotônicas e normotônicas. A média de procedimentos cirúrgicos realizados foi mais expressiva no grupo de crianças com hipertonia muscular. As sequelas motoras estiveram presentes em $92 \%$ da amostra. As atividades funcionais estáticas, bem como as dinâmicas, encontraram-se mais comprometidas nas crianças hipertônicas $(p<0,0001)$ do que nas hipotônicas e normotônicas. Conclusões: A hipertonia muscular foi a alteração tônica mais presente nas crianças com hidrocefalia, e a função motora é deficitária, sendo o atraso no desenvolvimento neuropsicomotor mais evidente no grupo de crianças espásticas e menos pronunciado nas crianças com tônus muscular sem alterações.

\section{PALAVRAS-CHAVE}

Criança, atividade motora, hidrocefalia, tônus muscular.

1. Physiotherapist. Mastering in Health Science at Universidade Federal de Sergipe (UFS), trainee professor at Universidade Tiradentes, Aracaju, SE, Brazil.

2. Ph.D. professor at the Medical Department at UFS, Aracaju, SE, Brazil.

3. Doctor in Biotechnology, professor at Universidade Tiradentes (UNIT), Aracaju, SE, Brazil. 


\section{Introduction}

Hydrocephalus is a pathological condition that causes cerebral ventricles dilation due to excessive accumulation of cerebrospinal fluid (CSF), which can also be followed by the increase of intracranial pressure. Even if it is controlled, it is frequently associated with learning disorders, poor motor skills and compromised life quality by several complications and incapacities. ${ }^{6,16}$

The child may present a tense and bulging fontanelle, thinning of the skull bone structure, opisthotonus, paresis or paralysis of cranial nerves, coma, muscle tone changes, breathing disorders, progressive visual loss, papilledema, motor deficit, functional limitation, lack of concentration, memory and learning disturbs, behavioral changes and sleeping disorders. ${ }^{4,5,15,24}$

Reestablishing functionality in children with hydrocephalus demands a deep knowledge of their motor skills. The delay in neuropsychomotor function developments, which is a limiting factor of children's potentialities, is one of the most concerning aspects. Moreover, the physiotherapist's acting in neurological disorders depends on the development of the evaluation system.

Due to the lack of published studies about motor deficits in hydrocephalus, there is the necessity to investigate kinetic and functional compromising in children with this condition in order to identify peculiar motor characteristics, for instance, the muscle tone changes and the functional activities, as well as knowing if there is a connection between them or not.

\section{Methodology}

It is an exploratory cross-sectional comparative study under qualitative and quantitative approach, developed in the ambulatory area at University Hospital of Universidade Federal de Sergipe (UFS), from August 2009 to March 2010. The children were evaluated individually, taking the variables into consideration, muscle tone and functionality.

Fifty children with hydrocephalus $(\mathrm{N}=50)$ have participated in this study. They were of both genders, with age above six months, without any previous diseases that could be related to muscle tone changes or delay in the neuropsychomotor development.

An identification file and the Durigon Protocol ${ }^{8}$ (with 3 ordinal scales) were used as data collection instruments. The first scale of the Durigon Protocol involves the evaluation of the muscle tone, which analyses the muscle reaction while being stretched, varying from one to ten degrees. One as being hypotonia, two as normal tone and from three to ten as the progres- sive increasing of hypertonia. The second scale consist of evaluating static functional activities for children, varying from zero to nine degrees, including sitting, quadruped, kneeling, half-kneeling and standing positions. The third scale is to evaluate dynamic functional activities for children, varying from zero to two degrees, corresponding to crawling and the gait.

The research data were organized in the SPSS program, version 17.0. After that, they underwent statistical analyses and used to arrange the children in each studied group. The chi-square test $\left(\mathrm{X}^{2}\right)$ for categorical variables and the T-test as well as the ANOVA for quantitative variables with Tukey post-hoc considering a significance level of $5 \%$ were used.

The study was approved at the Research Ethics Committee from the Universidade Federal de Sergipe, and the data collecting started after signing the Consent Terms by the children's parents or guardians.

\section{Results}

Initially, all the fifty children evaluated were divided into groups according to the results from the qualitative and quantitative approach, according to the muscle tone characterization. Thirty $(\mathrm{N}=30)$ presented spastic hypertonia (spasticity), corresponding to the Hypertonia Group; ten $(\mathrm{N}=10)$ presented hypotonia, the Hypotonia Group; ten $(\mathrm{N}=10)$ did not present muscle tone changes, representing the Normal Tone Group. There was a significant difference between normal tone group (66.20) and hypertonia group (29.07), according to the average age, with $\mathrm{p}<0.011$ (Table 1).

\begin{tabular}{lccccc}
\hline \multicolumn{5}{c}{ Table 1 - Age average according to muscle tone } \\
\hline Group & $\mathrm{N}$ & $\begin{array}{c}\text { Mean } \\
\text { (months) }\end{array}$ & $\begin{array}{c}\text { Standard } \\
\text { error }\end{array}$ & Min. & Max. \\
\hline Hypotonia & 10 & 43.50 & 29.960 & 06 & 104 \\
Normal tone & 10 & 66.20 & 45.752 & 08 & 144 \\
Hypertonia $^{*}$ & 30 & 29.07 & 28.149 & 06 & 107 \\
Total $^{*}$ & 50 & 39.38 & 35.124 & 06 & 144 \\
\hline
\end{tabular}

${ }^{*}$ p-value $=0.011<0.05$.

As for the gender, 29 (58\%) were males and $21(42 \%)$ were females. Thirty seven children $(74 \%)$ underwent a ventricular shunt and 13 (26\%) had not been operated. As for the diagnostic, 38 (76\%) presented hydrocephalus without myelomeningocele, and 12 (24\%) had hydrocephalus associated to myelomeningocele. The children who just presented hydrocephalus represented 30\% 
$(\mathrm{N}=3)$ of the hypotonic group, $90 \%(\mathrm{~N}=9)$ of the normal tone group and $86,7 \%(\mathrm{~N}=26)$ of the hypertonic group.

The mean of surgery performed was 1.7 in the Hypotonia Group and 1.17 in the Normal Tone Group; this mean was more expressive in the group of children with hypertonia (3.67).

It was observed that only $24(48 \%)$ children were submitted to physiotherapeutic treatment, whereas 26 (52\%) did not, although presenting motor deficit from this disease.

It was possible to observe that the motor sequel were present in 46 children (92\%), making 100\% in the children with hypotonia; $70 \%$ in those without muscle tone changes; and $96.7 \%$ in the hypertonic children (Table 2).

\begin{tabular}{|c|c|c|c|}
\hline \multirow{2}{*}{ Tone group } & \multicolumn{2}{|c|}{ Motor sequel } & \multirow{2}{*}{ Total } \\
\hline & No & Yes & \\
\hline \multirow[t]{2}{*}{ Hypotonia } & 0 & 10 & 10 \\
\hline & $0.0 \%$ & $100.0 \%$ & $100.0 \%$ \\
\hline \multirow[t]{2}{*}{ Normal tone } & 03 & 07 & 10 \\
\hline & $30.0 \%$ & $70.0 \%$ & $100.0 \%$ \\
\hline \multirow[t]{2}{*}{ Hypertonia } & 01 & 29 & 30 \\
\hline & $3.3 \%$ & $96.7 \%$ & $100.0 \%$ \\
\hline \multirow[t]{2}{*}{ Total } & 04 & 46 & 50 \\
\hline & $8.0 \%$ & $92.0 \%$ & $100.0 \%$ \\
\hline
\end{tabular}

p-value $=0.016<0.05$

A statistical significance was found among the groups concerning the static activities. As for sitting position, there was a statistical difference between spastic and hypotonic groups, as well as between spastic and normal tone groups, though the degree of sitting was lower in the spastic children. In the quadruped position analysis, there was a difference between hypotonia and normal tone groups, as well as hypertonia and normal tone groups, meaning that this degree is higher in the normal tonic children. In the kneeling and half-kneeling positions, a difference was noticed between the hypertonia and normal tone groups, as the degrees were lower in the spastic children. In the standing position, there was a statistic difference between the normal tone and hypotonia groups and between the normal tone and hypertonia groups, meaning that the standing degree is higher in the normal tonic children (Table 3 ).

It was observed that from the evaluated children $(\mathrm{N}=50), 40(80 \%)$ were 12 or more months old, and $10(20 \%)$ were younger than 12 months. To evaluate the dynamic functional activities, only the 12 or more months old children were recruited.

\begin{tabular}{|c|c|c|c|c|}
\hline $\begin{array}{l}\text { Static } \\
\text { activities }\end{array}$ & Muscle tone & $\mathbf{N}$ & $\begin{array}{l}\text { Points average } \\
\quad(\text { ranks })\end{array}$ & p-value ${ }^{*}$ \\
\hline \multirow[t]{4}{*}{ Sitting } & Hypotonia & 10 & 30,75 & 0,001 \\
\hline & Normal tone & 10 & 37,65 & \\
\hline & Hypertonia & 30 & 19,70 & \\
\hline & Total & 50 & & \\
\hline \multirow[t]{4}{*}{ Quadruped } & Hypotonia & 10 & 28,35 & 0,000 \\
\hline & Normal tone & 10 & 39,75 & \\
\hline & Hypertonia & 30 & 19,80 & \\
\hline & Total & 50 & & \\
\hline \multirow[t]{4}{*}{ Kneeling } & Hypotonia & 10 & 26,75 & 0,001 \\
\hline & Normal tone & 10 & 38,00 & \\
\hline & Hypertonia & 30 & 20,92 & \\
\hline & Total & 50 & & \\
\hline \multirow[t]{4}{*}{ Half-kneeling } & Hypotonia & 10 & 26,30 & 0,001 \\
\hline & Normal tone & 10 & 36,90 & \\
\hline & Hypertonia & 30 & 21,43 & \\
\hline & Total & 50 & & \\
\hline \multirow[t]{4}{*}{ Standing } & Hypotonia & 10 & 22,50 & 0,000 \\
\hline & Normal tone & 10 & 41,95 & \\
\hline & Hypertonia & 30 & 21,02 & \\
\hline & Total & 50 & & \\
\hline
\end{tabular}

* Significant average difference to the level of $5 \%(\mathrm{p}<0,05)$.

It was found that, in the three studied groups, the crawling activity was more frequent than the gait, although the two dynamic activities were more often in the normal tonic children. As for the children that presented tonic changes, it was verified that the hypertonic children had worse performance on these functional skills than the hypotonic children (Table 4).

\begin{tabular}{|c|c|c|c|c|}
\hline \multicolumn{5}{|c|}{$\begin{array}{c}\text { Table } 4 \text { - Dynamic functional activities }(\geq 12 \\
\text { months) in relation to muscle tone }\end{array}$} \\
\hline $\begin{array}{l}\text { Dynamic } \\
\text { activities }\end{array}$ & Muscle tone & $\mathbf{N}$ & $\begin{array}{l}\text { Points average } \\
\quad \text { (ranks) }\end{array}$ & p-value ${ }^{\star}$ \\
\hline \multirow[t]{4}{*}{ Crawling } & Hypotonia & 10 & 27,65 & 0,001 \\
\hline & Normal tone & 10 & 38,25 & \\
\hline & Hypertonia & 30 & 20,53 & \\
\hline & Total & 50 & & \\
\hline \multirow[t]{4}{*}{ Gait } & Hypotonia & 10 & 23,90 & 0,000 \\
\hline & Normal tone & 10 & 40,25 & \\
\hline & Hypertonia & 30 & 21,12 & \\
\hline & Total & 50 & & \\
\hline
\end{tabular}

* Significant average difference to the level of $5 \%(p<0,05)$. 


\section{Discussion}

The protocol of evaluation uses an objective measurement of changes occurred in the muscle tone and in the functional activities of children with cerebral paralysis, based on the motor performance characteristics, in accordance with the principles that rule the neural control. ${ }^{8}$ Due to the similarities of the tonic and motor characteristics presented, this protocol can be used to evaluate children with hydrocephalus, not having difficulties with its use, once the evaluation criteria related to this kind of disease was followed.

The average age of the evaluated children was 39.38 months old, being higher at normal tone children (66.20) and considerably lower in the hypertonic children (29.07), suggesting that lifespan will be longer for children without muscle tone changes and shorted for children with spasticity due to more frequent functional limitations in children with hypertonia.

The motor sequels found were much greater than those recorded in the literature, being present on $92 \%$ of the sample. The functional activities seemed poorer on the spastic and hypotonic children than on the children without muscle tone changes. In another study, ${ }^{3}$ deficit on the neuropsychomotor was observed in $60 \%$ of the casuistry, severely compromising life quality.

A previous research observed severe motor disorders in $34.3 \%$ of the sample. These authors ${ }^{17}$ claimed that the motor disorders are connected to the degree of hydrocephalus. In another study, ${ }^{14}$ there were $60 \%$ of motor deficit and $68 \%$ of cognitive deficit with low IQ on the casuistry compared to $25 \%$ of the visual and hearing deficits.

The findings showed an important relation between the number of surgeries and the presence of sequels, motor compromising being higher on spastic and hypotonic children and lower on children without muscle tone changes. Some authors ${ }^{20}$ found important loss of functioning on the superior members in 6 to 8 years old children, being worse on those children with hydrocephalus, submitted to ventricular shunt surgeries.

The literature describes that the number of changes of ventricular shunts due to complications is crucial to psychomotor disorders. ${ }^{11}$ It has also been reported that more than three shunt reviews were associated with poor motor function due to tissue damaged on the region. ${ }^{19}$

An investigation performed with 144 children with congenital hydrocephalus and 44 with hydrocephalus associated with myelomeningocele also found meaningful correlation between the number of ventricular peritoneal (VP) shunt reviews and motor function. ${ }^{21}$ On the other hand, some authors ${ }^{2}$ claimed that the placement of ventricular shunt provides a better neu- ropsychomotor development. The children that have undergone more than two surgeries have great chances of developing complications. ${ }^{11,18}$ Differently from other studies, one investigation has shown that the number of changes of ventricular shunts did not present risks to the psychomotor disturbs. ${ }^{17}$

The motor skills and the fine motor control are significantly under the average, and the presents of these deficits is justified in this population due to the hydrocephalus physiopathology that involves motor control cerebral areas. ${ }^{12}$ Children with myelomeningocele with or without hydrocephalus obtained lower movement dexterity scores than normal children. ${ }^{13}$

The relation between mobility, superior member functions and hydrocephalus in children with myelomeningocele has been examined and a pyramidal tract dysfunction was found. Sixty-nine percent of the children presented superior members function disorders. This percentage was greater in children with hydrocephalus. ${ }^{25}$

As for the motor disorder predominance, it can be observed that there has not been statistically significant difference between the right and left hemispheres, which characterizes hydrocephalus as a disease of symmetric implication, related to the muscle tone changes in the body hemispheres, although there is no records in literature that corroborate with these findings.

Some authors claim the increase of muscle tone (spasticity) with opisthotonus, besides motor disorder., ${ }^{4,5}$ As the disease evolutes, the tendons reflexes sensibility and the muscle tone are increased. ${ }^{22}$

The pyramidal syndrome (especially in the lower members) many times manifested as a spastic tetraparesis, constitutes a common characteristic of the children with hydrocephalus. ${ }^{10}$ On the contrary, the flaccid paraplegia is the most evident motor implication on children with myelomeningocele. ${ }^{23}$

There has been a statistical significance between the groups of tones concerning the static activities of the children with hydrocephalus. Considering the positions Sitting, Quadruped, Kneeling, Half-kneeling and Standing, lower degrees on spastic and higher on normal tonic children were observed, demonstrating that exacerbation of muscle tone negatively influences the realization of functional activities of the children.

Concerning the dynamic functional activities, very significant results were recorded, in other words, lower degrees on spastic children and higher on children of the normal tone group, representing that the children with spasticity show greater motor limitations, whereas children with normal tone have greater ability to perform these functional activities.

There is a relation between spasticity and motor function yet not clarified. There are many clinical evidences that the spasticity limits the voluntary move- 
ments, having a correlation between the degree of spasticity and the functional capacity. ${ }^{9}$ The influence of stretch reflex in a hypertonia have great negative effects on the motor development and on the life quality of patients with a motor superior neuron damage. ${ }^{1}$

Due to the great importance of the normal motor function, which depends on normal physical and intellectual capacity, suitable motor skills are essential to patients to integrate then in the community. Motor learning deficits have been identified in other neurological disorders. However, very few studies have approached this deficit on children with hydrocephalus. ${ }^{7}$

The data obtained in this study allow us to observe that the protocol to evaluate the muscle tone and the static functional activities serve as an instrument of great value to quantify and qualify the kinetic functional condition of the children with hydrocephalus. Therefore, it is believed that this research may help medical professionals who work with these children, especially the physiotherapists, in order to establish the suitable criteria to evaluate the motor function.

\section{References}

1. Benz EN, Hornby TG, Bode RK, Scheidt RA, Schmit BD. A physiologically based clinical measure for spastic reflexes in spinal cord injury. Arch Phys Med Rehabil. 2005;86(1):52-9.

2. Brouwer A, Groenendaal F, Van Haastert IL, Rademaker K, Hanlo P, De Vries L. Neurodevelopmental outcome of preterm infants with severe intraventricular hemorrhage and therapy for post-hemorrhagic ventricular dilatation. J Pediatr. 2008;152(5):648-54.

3. Caldarelli M, Di Rocco C, La Marca F. Shunt complications in the first postoperative year in children with meningomyelocele. Childs Nerv Syst. 1996;12(12):748-54.

4. Chiafery M. Care and management of the child with shunted hydrocephalus. Pediatr Nurs. 2006;32(3):222-5.

5. Cochrane DD, Kestle J. Ventricular shunting for hydrocephalus in children: patients, procedures, surgeons and institutions in English Canada, 1989-2001. Eur J Pediatr Surg. 2002;12(Suppl 1):S6-11.

6. Del Bigio MR. Pathophysiologic consequences of hydrocephalus. Neurosurg Clin N Am. 2001;12(4):639-49.

7. Ding Y, Lai Q, McAllister II JP, Canady Al. Impaired motor learning in children with hydrocephalus. Pediatr Neurosurg. 2001;34(4):182-9.

8. Durigon OFS, Sá CSS, Sitta LV. Validação de um protocolo de avaliação do tono muscular e atividades funcionais para crianças com paralisia cerebral. Rev Neuroc. 2004;12(2):87-93.

9. Foran JR, Steinman S, Barash I, Chambers HG, Lieber RL. Structural and mechanical alterations in spastic skeletal muscle. Dev Med Child Neurol. 2005;47(10):713-7.
10. Futagi Y, Suzuki Y, Toribe Y, Morimoto K. Neurodevelopmental outcome in children with fetal hydrocephalus. Pediatr Neurol. 2002;27(2):111-6.

11. Heinsbergen I, Rotteveel J, Roeleveld N, Grotenhuis A. Outcome in shunted hydrocephalic children. Eur J Paediatr Neurol. 2002;6(2):99-107.

12. Hetherington R, Dennis M. Motor function profile in children with early onset hydrocephalus. Devel Neuropsychol. 2000;15(1):25-51.

13. Holler KA, Fennell EB, Crosson B, Boggs SR. Neuropsychological and adaptive functioning in younger versus older children shunted for hydrocephalus. Child Neuropsychol. 1995;1(1):67-73.

14. Hoppe-Hirsch E, Laroussinie F, Brunet L, Sainte-Rose C, Renier D, Cinalli G, et al. Late outcome of the surgical treatment of hydrocephalus. Childs Nerv Syst. 1998;14(3):97-9.

15. Hwang YS, Shim I, Chang JW. The behavioral change of locomotor activity in a kaolin-induced hydrocephalus rat model: evaluation of the effect on the dopaminergic system with progressive ventricle dilatation. Neurosci Lett. 2009;462(3):198-202.

16. Iqbal MM. Prevention of neural tube defects by periconceptional use of folic acid. Pediatr Rev. 2000;21(2):58-66.

17. Kliemann SE, Rosemberg S. [Shunted hydrocephalus in childhood: an epidemiological study of 243 consecutive observations]. Arq Neuropsiquiatr. 2005;63(2B):494-501.

18. Kulkarni AV, Rabin D, Lamberti-Pasculli M, Drake JM. Repeat cerebrospinal fluid shunt infection in children. Pediatr Neurosurg. 2001;35(2):66-71.

19. Mazur JM, Aylward GP, Colliver J, Stacey J, Menelaus M. Impaired mental capabilities and hand function in myelomeningocele patients. Z Kinderchir. 1988;43(Suppl 2):24-7.

20. Minns, RA, Sobkowiak CA. Upper limb function in spina bífida. Zeitschrift für Kinderchirurgie. 1977;22(4):493-506.

21. Persson EK, Hagberg G, Uvebrant P. Disabilities in children with hydrocephalus - a population-based study of children aged between four and twelve years. Neuropediatrics. 2006;37(6):330-6.

22. Rizvi R, Anjum Q. Hydrocephalus in children. J Pak Med Assoc. 2005;55(11):502-7.

23. Rocco FM, Saito ET, Fernandes AC. Perfil dos pacientes com mielomeningocele da Associação de Assistência à Criança Deficiente (AACD) em São Paulo - SP, Brasil. Acta Fisiatr. 2007;14(3):130-3.

24. Schwanitz G, Schüler H, Gembruch U, Zerres K. Chromosomal findings in fetuses with ultrasonographically diagnosed ventriculomegaly. Ann Genet. 1993;36(3):150-3.

25. Wallace SJ. The effect of upper-limb function on mobility of children with myelomeningocele. Dev Med Child Neurol Suppl. 1973:Suppl 29:84-91.

Correspondence address

Aida Carla Santana de Melo Costa

Av. Adélia Franco, 2403, bloco A, ap. 804 - Grageru, Aracaju, SE, Brazil

E-mail: aida-fisio@hotmail.com 